\title{
Participation and Independence with Low Literacy: Selected Findings of the LEO 2018 Survey on Low Literacy in Germany
}

Klaus Buddeberg, Gregor Dutz, Lisanne Heilmann, Christopher Stammer, and Anke Grotlüschen, Hamburg University

\begin{abstract}
This paper presents findings by the LEO Survey 2018 - Living with Low Literacy. It found that in Germany $12.1 \%$ of the adult population (aged between 18 and 64 years) have low literacy skills. This paper questions existing assumptions about the everyday life of adults with low literacy. Based on variables on everyday practices, we work out in which areas of life low literacy leads to exclusion from participation - specifically in terms of health, politics, and digital practices. While our analysis did not find an exclusion in online writing, it revealed differences in the autonomy and in the ability to understand information and to assess its trustworthiness for adults with low literacy skills.
\end{abstract}

Keywords: low literacy, educational benefits, participation

The discussion on basic education and on literacy often focuses on the relationship between literacy skills and one's autonomy and participation in daily life. Adult education promises to be beneficial for societal and economic development (Organisation for Economic Co-operation and Development [OECD], 2013, 2018) as well as for individual wellbeing:

Adult education and training (AET) represent an important opportunity for adults with low literacy and numeracy proficiencies to improve their competences and consequently their chances for better integration in the economic and social life and overall personal wellbeing. (Grotlüschen et al., 2016, p. 10)
The large-scale literacy assessment LEO Survey 2018 - Living with Low Literacy (LEO 2018) looked at the German-speaking adult population between 18 and 64 years of age. The survey found that in 2018 in Germany $12.1 \%$ of the adult population have low literacy skills. These 12.1\% equal 6.2 million adults (Grotlüschen et al., 2020a). Based on these data, we look at the specific relation between literacy skills and individual benefits in term of autonomy and participation. To this end, we have examined several everyday practices and basic skills for their connection with the level of literacy. In some cases, we find a clear correlation between these practices and the level of reading and writing skills. 


\section{Literature Review}

\section{Literacy as More Than Reading and Writing}

Talking about literacy, we often look at a continuum between literate and illiterate as the competence to read and write. This literacy is then related to social exclusion. Sometimes we might even look for a concrete threshold, a suitable minimum, beyond which social participation is granted and below which education is required and offered. As a result, educational research and practice are directed towards short-term, quantifiable educational outcomes (e.g., higher literacy scores, cf. Tillmann et al., 2008; Waldow, 2009). In this paper, we use a large-scale survey to argue for a broader and more diverse understanding of education and basic competences instead. Relating literacy scores to everyday practices and self-reported competences allows us to question in which areas of everyday life a "minimum" of literacy skills is actually required to facilitate participation and in which areas other skills or factors need to be taken in account instead of or in addition to literacy.

The term basic education is often used to describe a minimum level of competences that people must have in order to participate in society. To this end, specific areas must be defined, and competences have to be identified.

LEO 2018 draws on a definition of literacy, which emphasizes the importance of reading and writing skills as a societal requirement. Here, a low level of literacy is described as reading and writing skills below the suitable minimum, which is required and assumed necessary for fulfilling social requirements (Egloff et al., 2011).

However, definitions of literacy are diverse and competing (UNESCO, 2005). Street $(1984,2003)$ introduced a view of literacy that acknowledges the performative impact of power structures on literacy practices. The skill, its use, assessment, and value are embedded in a social context (Reder, 2017). In this embeddedness, one can no longer assume just one "right" literacy, but rather multiple literacy practices that emerge from different social contexts (cf. 2003; Reder \& Davila, 2005).

One of these multiple implementations of literacy is critical literacy. Referring to Freire (2014), critical literacy describes a critical orientation in and through one's literacy. It is relevant for transforming environments as well as one's position in them. Among the essential competences of a person are the abilities to read about one's environment, to write and participate in public debates, as well as to understand, question and reflect written information in order to comprehend one's own relation to the environment (Negt, 1969, 1993; Zeuner, 2007).

Quantitative surveys report some correlations between the level of reading and writing skills and various sociodemographic and socioeconomic factors like age, gender, educational level, employment or first language (OECD, 2013; Grotlüschen et al., 2014; Grotlüschen et al., 2020b). Andreasson (2015) has described a fundamental inequality in the distribution of benefits and risks of digitalization. Health related issues and their correlation with sociodemographic and socioeconomic factors have been reported in the European Health Literacy Survey (HLSEU; Sørensen et al., 2015). The influence of individual characteristics as education or gender on political actions is well documented (van Deth, 2016). In addition to these sociodemographic variables, confounders like a general interest in a topic (such as health 
or politics) can be assumed to increase one's frequency and depth of engagement with the topic.

\section{Literacy and Vulnerability}

There is broad (mainly qualitative) research on the meaning and impact of (low) literacy in everyday life situations (e.g., chapters in Barton et al., 2003; Zeuner \& Pabst, 2011). It often elucidates that specific vulnerability resulting from low literacy needs to be examined in more detail. We define vulnerability as "an identifiably increased likelihood of incurring additional or greater wrong" (Hurst, 2008, p. 191). To identify these likelihoods, different areas of life need to be examined which might show elements of exclusion or participation. In this paper, we focus on digital, political, and health-related practices, as these belong to the main domains of adult basic education in the framework of the national campaign on adult basic education in Germany (Grotlüschen, 2016).

\section{Digital Practices}

The internet represents an increasing opportunity to find information, for example on topics related to health risks or benefits. Online sources can offer a valuable supplement to conventional sources of information (Andreassen et al., 2007) but also present new challenges. The means to cope with these new challenges, however, are not distributed equally across the general population. The term "digital divide" or "digital inequality" describes a consolidating inequality in internet access (Andreasson, 2015). This unequal distribution is not limited to the question of access, but also impacts different usage patterns. The benefits of digital opportunities are distributed unequally, depending on technical, financial, and social resources. Zillien and Marr (2013) therefore assumed, that "the Internet will reinforce or even increase existing social inequalities" (p. 64). One of these cultural resources determining the benefits of online inclusion might be literacy. Smythe and Breshears (2017) discuss that most internet services appear to be designed for "model users" and systematically exclude certain subgroups.

\section{Political Practices}

A lower literacy level is accompanied by lower political self-efficacy expectations and less social trust, as a secondary analysis of Program for the International Assessment of Adult Competencies (PIAAC) data showed (Grotlüschen, Chachashvili-Bolotin, et al., 2020). It appears to be more difficult to express a political opinion for those having low literacy skills, also because they feel not competent or entitled to express an opinion on political topics (Bremer \& Pape, 2017). Especially those means of political expression that include sophisticated forms of language and literacy are more difficult to master for adults with low literacy skills. Means of political expression with lower literacy thresholds might not always be acknowledged by narrower concepts of political participation. These practices are often seen as less valuable or valid (Zeuner \& Pabst, 2011), or simply as "less political." Further quantitative research showed that political practices like volunteering, reading papers, party membership or debating political issues, are not predominantly determined by literacy proficiency but by general educational background and social circumstances of living (Dutz \& Heilmann, 2019).

\section{Health-related Practices}

Another possible impact of low literacy skills may be higher health risks. A correlation between the general educational attainment 
and health outcomes can be shown (Borgonovi \& Pokropek, 2016, p. 2) as well as relation of health-related competences and health outcomes (Sørensen et al., 2015). Although there is a fundamental aim to provide basic health and medical care, which is accessible to everyone, still health disparities and social selectivity are apparent. Age (Lampert \& Kroll, 2010 , p. 3), social class (Geyer, 2008), income, education, and work (Richter \& Hurrelmann, 2009, p. 13) are key factors to determine health inequalities.

These differences are not determined by behavioral preferences that are specific to one social class (Cutler \& Lleras-Muney, 2010), but rather an accumulation of multiple educational and environmental factors (Vahtera et al., 1999). The HLS-EU points out, that access to information can be a relevant factor for health (Sørensen et al., 2015). Especially if a healthrelevant information is mainly or exclusively available in written form, this could pose additional obstacles for adults who have low literacy skills. Harris et al. (2019) particularly discuss the aspect of eHealth literacy, which creates further possible sources of unequal access to information.

\section{Research Questions}

Given the embeddedness of literacy and, increasingly digital literacy, in daily life, we need to ask how and where a low level of literacy might become a factor of exclusion. We looked especially at exclusion in terms of (1) digitalization, (2) autonomy and (3) critical skills as three possible moments of exclusion. As these are not expected to be solely related to literacy skills but rather to a multiplicity of social, demographic, and educational circumstances, we choose to add multiple background variables.
Educational attainment, employment status, age, or native languages have been shown to relate to and influence behavior and practices.

As digitalization is offering new opportunities but also new barriers, we need to know what role literacy competences play in order to better understand how literacy education could improve adult's digital participation. For some people, the digital world can mean a gain in independence. To cover this perspective on literacy skills, we ask two research questions:

- (1a) Controlling for employment status, educational attainment, etc., how does searching the internet for information on health-related topics correlate with literacy skills?

- (1b) Controlling for employment status, educational attainment, etc., how does writing comments about articles on the internet correlate with literacy skills?

Based on earlier research our hypothesis is that both literacy practices are positively related with literacy skills: Adults with low literacy skills perform these literacy practices less often.

Being independent and autonomous can be described as a basic human need (Doyal \& Gough, 1991, p. 59). Therefore, it would be problematic if societies would penalize low literacy skills with dependency. To analyze this aspect, we ask the following two questions:

- (2a) Controlling for employment status, educational attainment, etc., how does the need for support when filling out healthrelated forms correlate with literacy skills?

- (2b) Controlling for employment status, educational attainment, etc., how does the need for support when filling out official forms correlate with literacy skills? 
Here our hypothesis is that the need for support when dealing with forms is negatively related to literacy skills: Adults with low literacy skills require support more often.

Especially in situations of dependency, it is important to understand and critically reflect those dependencies in one's own life in order to break free. This critical understanding of information and interrelations is necessary for a self-determined life, which should not be only available to highly literate people. To get some insight into these relations, our research questions are:

- (3a) Controlling for employment status, educational attainment, etc., how does the ability to critically judge the trustworthiness of media coverage about a disease correlate with literacy skills?

- (3b) Controlling for employment status, educational attainment, etc., how does the ability to understand and assess important political issues correlate with literacy skills?

Finally, we hypothesize that the ability to critically judge information and issues is positively related to literacy skills: Adults with low literacy skills have more difficulties when it comes to critically judging and assessing such topics.

To answer these research questions and to test our hypothesis, we will use the LEO 2018 data to look at the relation of these practices and competences with low literacy among adults in Germany. For each of the research questions, we chose two exemplary practices or competences that are either digital, politic-related, or health-related. With these examples, we will present indicators towards the inclusion and exclusion of adults with low literacy regarding digitalization, independence, and critical literacy.

\section{Data and Method}

The LEO 2018 is a household survey based on a sample of 7,192 cases. It was conducted by Hamburg University and funded by the German Federal Ministry for Education and Research in the context of the so-called National Decade for Alphabetization and Adult Basic Education. It is representative for the German speaking population living in private households aged between 18 and 64 years. It comprises an extensive questionnaire and a literacy assessment. The questionnaire covers four domains of practices and competences: health, politics, financial, and digital. Across these domains, everyday practices as well as selfreported practical and critical competences are surveyed. At the end of the interview, a literacy assessment was carried out.

In the context of the theoretical framework of LEO 2018 literacy skills are measured in so-called alpha levels. Three alpha levels are describing the lower end of that scale. Literacy skills on alpha level 1 correspond to reading and writing on a level of letters. Adults who have literacy skills equivalent to alpha level 2 can read and write on the level of words. Skills in alpha level 3 describe reading and writing of simple sentences. Reading and writing of continuous texts - even short ones - goes beyond these skills. In LEO 2018, the term low literacy subsumes skills on these three levels. Adults with skill in alpha level 4 can read and write texts but show substantial difficulties with orthography. All those above alpha level 4 are grouped together without further distinction, as the focus of the LEO-survey lies at the lower end of the literacy scale (Grotlüschen et al., 2019).

\section{Dependent Variables}

The first set of research questions (1a) and (1b) 
on the digital ways of gathering and sharing information was operationalized by the following two questions:

(1a) How often do you search the internet for information on health-related topics such as nutrition, exercise and sport, illnesses or types of treatment?

(1b) How often do you write comments about articles on the internet, e.g. on news websites or on Facebook?

The objective of these questions is to find out about the frequency the practices are applied. The question does not directly allow answering about the motives for doing so (or not doing so). The response scale for both questions is daily, at least once a week but not daily, less often than once a week, less often than once a month, or never. To get a binary variable for the logistic regression models we grouped the respondents into two categories: Those who never search the internet for information on health-related topics respectively never write comments about articles on the internet, compared to those respondents who do so, at least infrequently.

For the second set of questions ( $2 \mathrm{a}$ and $2 \mathrm{~b}$ ), we looked at two variables on adult's usage of assistance in filling in official forms.

(2a) Do you fill out [health-related] forms (e.g. doctor's forms, hospital forms, nursing home forms or health insurance forms) on your own or are you looking for support?

(2b) Do you fill in applications with authorities such as the employment agency, the social welfare office or the housing benefit office independently ... or ... with support?

The response scale for both questions is independently, sometimes with support, or always with support. For the regression models we formed two groups for each question, one group representing respondents who always fill out mentioned paperwork with support, another group who depends on support less frequently or fills out forms independently.
Finally, we answered the third set of research questions ( $3 \mathrm{a}$ and $3 \mathrm{~b}$ ) on critically judging information with the help of two questions on critical competences.

(3a) Is it for you easy ... or difficult to judge whether media coverage about a disease is trustworthy?

(3b) Do you think you can understand and assess important political issues well?

Here the response scale for both questions is easy, rather easy, rather difficult and difficult. In order to obtain a binary variable for the logistic regression models we formed two groups of respondents: those who answered easy/rather easy and those who answered difficult/rather difficult on the other hand.

\section{Analytical Approach}

For each of those variables two regression models were constructed. The first one relates the variable to the different Alpha Levels and therefore describes the correlation between literacy and the variable without controlling for any other factors. In the respective second model, we added background variables to the regression analysis (the reference category in parentheses): literacy (above Alpha Level 4), educational attainment (high educational attainment); employment status (full-time employed); age groups (18-24); German as a second or foreign language (German as first language), general interest in health topics/political topics (no reference category, continuous variable). Further control variables are specified for each analysis. The selection of control variables is based on an assessment of earlier research mentioned above.

We used binary logistic regression analyses to determine the role that literacy plays in the execution of everyday practices and in understanding and judging information. 


\section{Findings}

Overall, the analyses showed different degrees of correlation between adults' experience in their practices, competences, and literacies. In this paper we cannot present all bivariate results differentiating the practices and competences by literacy levels. Part of these findings are reported in English in Grotlüschen et al. (2019, 2020a). The full set of results is reported in German in Grotlüschen and Buddeberg (2020).

\section{Reading and Writing Online}

A main aspect of social participation in the $21^{\text {st }}$ century is the ability to use and interact with digital media. The internet can be a source of information, for example regarding treatment for illnesses or on staying healthy. Especially in social media, writing and commenting can be forms of social participation on the internet.

Both practices of the first two research questions (searching the internet for healthrelated information and writing comments on the internet) include aspects of reading and writing as well as context-specific abilities and literacies. Based on the LEO questions, we can have a closer look at the relation of having low literacy skills and the ability to perform these practices. Table 1 shows these results. In the uncontrolled models (Models A1 and B1), an immediate difference between the two variables appears. Adults with literacy in the first three alpha levels are less likely to search on the internet for health-related information but having low literacy skills has no significant relation to writing a comment online. This table (as all further tables as well) depicts the odds ratios of the predictor variables. They can be understood as the change of probability that comes along with the respective predictor variable statistically. The Model A1 shows that adults who scored in alpha level 4 are almost half as likely (0.55) to search for health-related information on the internet than the reference group, which are those adults who score above alpha level 4 . The probability that an adult in alpha level 2 does so is one third of that of an adult above alpha level 4 . When we control this relation for the background variables, which could influence health-related behavior (Model A2), we see that the odds ratios for the alpha levels remain significant. Adults whose literacy scored in alpha level 1 are on average only four percent as likely to look for health-related information on the internet as adult with a high literacy (above alpha level 4). Other significant predictors for the use of the internet to find health-related information are the educational attainment and one's general interest in health topics. Adults with a high educational attainment are about twice as likely to use this practice as other adults, even if they have an equivalent literacy level. These findings indicate that literacy does play a role for online health searches, but educational attainment, which might indicate towards social class, seems to be an additional predictor.

Interestingly, the literacy practice to comment on online news articles does not show any significant values for literacy or educational attainment. Instead, the general interest in political topics and different age groups show to be statistical predictors for this practice. This means that the older a person is the less likely they are to comment online regardless of their attributed alpha level. 
Table 1: Odds ratios for models of the predictors of using the internet to ...

\begin{tabular}{|c|c|c|c|c|c|c|c|c|c|c|c|c|c|c|c|}
\hline \multirow{3}{*}{$\begin{array}{l}\text { Predictor } \\
\text { Intercept }\end{array}$} & \multicolumn{8}{|c|}{... search for health-related information } & \multicolumn{7}{|c|}{... comment on news articles } \\
\hline & \multicolumn{3}{|c|}{ Model A1 } & & \multicolumn{3}{|c|}{ Model A2 } & & \multicolumn{3}{|c|}{ Model B1 } & & \multicolumn{3}{|c|}{ Model B2 } \\
\hline & 4.05 & $* * *$ & $(1.05)$ & & 29.25 & $* * *$ & (1.32) & & 0.30 & *** & $(1.05)$ & & 0.58 & * & $(1.27)$ \\
\hline $\begin{array}{l}\text { Literacy Level } \\
\text { (ref.: Above level 4) }\end{array}$ & & & & --- & & & & --- & & & & --- & & & \\
\hline Alpha level 1 & 0.03 & $* *$ & (3.03) & & 0.04 & * & (3.60) & & 0.28 & & $(4.04)$ & & 0.24 & & $(4.03)$ \\
\hline Alpha level 2 & 0.33 & *** & (1.33) & & 0.39 & $*$ & $(1.45)$ & & 1.36 & & (1.35) & & 1.53 & & $(1.37)$ \\
\hline Alpha level 3 & 0.44 & $* * *$ & $(1.21)$ & & 0.57 & * & $(1.25)$ & & 1.25 & & (1.22) & & 1.32 & & (1.25) \\
\hline Alpha level 4 & 0.55 & $* * *$ & $(1.13)$ & & 0.7 & $*$ & $(1.15)$ & & 1.09 & & $(1.12)$ & & 1.13 & & (1.14) \\
\hline \multicolumn{16}{|l|}{$\begin{array}{l}\text { Educational attainment } \\
\text { (ref.: high attainment) }\end{array}$} \\
\hline No educational attainment & & & & & 0.48 & $* *$ & $(1.26)$ & & & & & & 0.94 & & (1.28) \\
\hline $\begin{array}{l}\text { Low educational } \\
\text { attainment }\end{array}$ & & & & & 0.43 & $* * *$ & $(1.14)$ & & & & & & 0.96 & & (1.13) \\
\hline $\begin{array}{l}\text { Medium educational } \\
\text { attainment }\end{array}$ & & & & & 0.52 & $* * *$ & (1.12) & & & & & & 1.01 & & (1.11) \\
\hline Still going to school & & & & & 0.44 & $* *$ & (1.34) & & & & & & 1.06 & & (1.36) \\
\hline \multicolumn{16}{|l|}{$\begin{array}{l}\text { Employment status (ref.: } \\
\text { full-time employed) }\end{array}$} \\
\hline Part-time employed & & & & & 1.22 & & (1.12) & & & & & & 0.98 & & (1.11) \\
\hline Unemployed & & & & & 0.81 & & (1.19) & & & & & & 1.11 & & (1.19) \\
\hline $\begin{array}{l}\text { in school, university, } \\
\text { vocational training, } \\
\text { voluntary year }\end{array}$ & & & & & 1.20 & & (1.22) & & & & & & 0.99 & & (1.18) \\
\hline Pensioner & & & & & 0.83 & & (1.18) & & & & & & 1.00 & & (1.19) \\
\hline Unable to work & & & & & 0.65 & & (1.35) & & & & & & 0.76 & & (1.34) \\
\hline other & & & & & 1.33 & & (1.18) & & & & & & 0.80 & & (1.15) \\
\hline \multicolumn{16}{|l|}{$\begin{array}{l}\text { Age group (ref.: 18-24 } \\
\text { years) }\end{array}$} \\
\hline $25-34$ years & & & & & 0.95 & & (1.18) & & & & & & 0.89 & & (1.16) \\
\hline $35-44$ years & & & & & 0.93 & & (1.19) & & & & & & 0.59 & $* *$ & (1.18) \\
\hline 45-54 years & & & & & 0.96 & & (1.19) & & & & & & 0.40 & $* * *$ & (1.18) \\
\hline $55-64$ years & & & & & 0.73 & & (1.19) & & & & & & 0.38 & $* * *$ & (1.19) \\
\hline $\begin{array}{l}\text { Low general interest in } \\
\text { health/political topics }\end{array}$ & & & & & 0.46 & $* * *$ & $(1.05)$ & & & & & & 0.87 & $* * *$ & (1.04) \\
\hline $\begin{array}{l}\text { Non-native German } \\
\text { speaker }\end{array}$ & & & & & 1.37 & & $(1.19)$ & & & & & & 1.24 & & (1.17) \\
\hline$R^{2}$ & 0.029 & & & & 0.159 & & & & 0.002 & & & & 0.029 & & \\
\hline
\end{tabular}

Note. Exponents of standard errors are in parentheses. Ref. $=$ reference category. Cont. = continuous variable. Source LEO $2018-$ living with low literacy. Base: German speaking adults $(n=7.192) . * * * p<.001 .{ }^{* *} p<.01 .{ }^{*} p<.05$. 


\section{Using Assistance to Fill Out Forms}

We then looked at forms and applications that need to be filled in to gain access for example to health care services or social benefits.
Table 2 shows the odds ratios (the changes in probability) for being dependent on assistance when filling out health forms and application forms.

Table 2: Odds-ratios for models of the predictors of always using support to fill in health-related forms and social applications

\begin{tabular}{|c|c|c|c|c|c|c|c|c|c|c|c|c|}
\hline \multirow{3}{*}{$\begin{array}{l}\text { Predictor } \\
\text { Intercept }\end{array}$} & \multicolumn{6}{|c|}{ Health-related forms } & \multicolumn{6}{|c|}{ Applications at social offices } \\
\hline & \multicolumn{3}{|c|}{ Model C1 } & \multicolumn{3}{|c|}{ Model C2 } & \multicolumn{3}{|c|}{ Model D1 } & \multicolumn{3}{|c|}{ Model D2 } \\
\hline & 0.01 & & $(1.28)$ & 0.00 & $* * *$ & $(2.07)$ & 0.02 & $* * *$ & $(1.36)$ & 0.01 & *** & $(2.44)$ \\
\hline Literacy Level (ref.: Above level 4) & & & & -- & & & -- & & & -- & & \\
\hline Alpha level 1 & 181.48 & $* * *$ & (2.23) & 96.61 & $* * *$ & $(2.73)$ & 166.02 & $* * *$ & $(2.72)$ & 92.07 & $* * *$ & (3.12) \\
\hline Alpha level 2 & 18.65 & $* * *$ & $(1.67)$ & 7.84 & ** & $(1.90)$ & 17.50 & $* * *$ & $(1.79)$ & 6.78 & * & $(2.24)$ \\
\hline Alpha level 3 & 7.42 & $* * *$ & $(1.48)$ & 3.60 & $*$ & $(1.67)$ & 6.95 & $* * *$ & $(1.58)$ & 3.11 & $*$ & $(1.73)$ \\
\hline Alpha level 4 & 2.98 & * & $(1.60)$ & 1.87 & & $(1.73)$ & 2.54 & & $(1.74)$ & 1.23 & & $(1.89)$ \\
\hline \multicolumn{13}{|l|}{ Educational attainment (ref.: high attainment) } \\
\hline No educational attainment & & & & 10.39 & $* * *$ & $(1.80)$ & & & & 7.45 & ** & $(1.83)$ \\
\hline Low educational attainment & & & & 4.96 & $* *$ & $(1.69)$ & & & & 4.58 & $* *$ & $(1.67)$ \\
\hline Medium educational attainment & & & & 2.63 & * & $(1.61)$ & & & & 1.46 & & $(1.66)$ \\
\hline Still going to school & & & & 3.10 & & $(2.34)$ & & & & 12.58 & ** & $(2.37)$ \\
\hline \multicolumn{13}{|l|}{ Employment status (ref.: full-time employed) } \\
\hline Part-time employed & & & & 0.58 & & $(1.51)$ & & & & 1.50 & & $(1.77)$ \\
\hline Unemployed & & & & 0.85 & & $(1.78)$ & & & & 1.26 & & $(1.74)$ \\
\hline $\begin{array}{l}\text { In school, university, vocational training, } \\
\text { voluntary year }\end{array}$ & & & & 1.50 & & $(1.71)$ & & & & 0.95 & & $(2.24)$ \\
\hline Pensioner & & & & 1.82 & & $(1.62)$ & & & & 4.17 & & $(2.13)$ \\
\hline Unable to work & & & & 2.60 & & $(1.63)$ & & & & 9.53 & $* *$ & $(2.02)$ \\
\hline Other & & & & 1.22 & & $(1.55)$ & & & & 1.92 & & (1.99) \\
\hline \multicolumn{13}{|l|}{ Age group (ref.: 18-24 years) } \\
\hline 25-34 years & & & & 0.51 & & $(1.67)$ & & & & 0.49 & & $(1.72)$ \\
\hline $35-44$ years & & & & 0.55 & & $(1.80)$ & & & & 0.57 & & $(1.84)$ \\
\hline $45-54$ years & & & & 0.53 & & $(1.73)$ & & & & 0.48 & & $(1.81)$ \\
\hline $55-64$ years & & & & 0.28 & $*$ & $(1.74)$ & & & & 0.74 & & $(1.85)$ \\
\hline Frequency of facing such forms (cont.) & & & & 1.29 & ** & $(1.09)$ & & & & & & \\
\hline Poor subjective health status (cont.) & & & & 1.37 & $*$ & $(1.13)$ & & & & & & \\
\hline Non-native German speaker & & & & 0.88 & & $(1.46)$ & & & & 1.59 & & $(1.67)$ \\
\hline $\mathrm{R}^{2}$ & 0.176 & & & 0.252 & & & 0.217 & & & 0.323 & & \\
\hline
\end{tabular}

Note. Exponents of standard errors are in parentheses. Ref. = reference category. Cont. = continuous variable. Source: LEO $2018-$ living with low literacy. Base: German speaking adults $(n=7.192) . * * * p<.001 .{ }^{* *} p<.01 .{ }^{*} p<.05$. 
The Models C1 and C2 in Table 2 depict the regression results for always using support to fill in health-related forms. The Models D1 and D2 depict the results for always using support to fill in application forms at social authorities. All four models show that adults who have low literacy skills are more likely to use support. In both controlled models (C2 and D2), there is no significant difference between adults in alpha level 4 and those above alpha level 4 . Adults with literacy scores in alpha level 2 and 3 are multiple times more likely to use assistance in filling out their form and to an even greater extent this applies to alpha level 1. We see again that the educational attainment is a significant predictor. The lower the educational attainment the more likely adults are to be assisted in filling out their forms.

\section{Judging Trustworthiness of Media Information}

Reading and writing may be essential parts of participating in certain fields, but these skills are less helpful without understanding and being able to judge whether the found information is trustworthy. In the same way, feeling able to understand political issues might be relevant in taking part in political online discussions.
Having low literacy skills relates to lower feelings of competence regarding understanding and judging information. It is less probable that adults who have low literacy skills feel they can judge the trustworthiness of health-related information in the media (Table 3, Model E1, E2) or understand and assess relevant political topics (Model F1, F2). However, when controlled for background variables the odds ratios for both cases become less significant. Instead, the educational predictor variables are highly significant and show that - in comparison to adults with high educational attainments adults with medium, low, or no educational attainment are less likely to report these levels of competences. The probability of adults with low or no attainment to feel confident in judging and assessing these topics is half as high as among adults with high educational attainments.

For both competences, the adults who are unable to work also show lower confidence in their competence to judge these topics. Additionally, non-native German speakers are half as likely to feel that they can understand and assess relevant political topics.

\section{Table 3: Odds-ratios for models of the predictors for feeling able to judge and understand information without difficulties}

\begin{tabular}{|c|c|c|c|c|c|c|c|c|c|c|c|c|}
\hline \multirow{3}{*}{$\begin{array}{l}\text { Predictor } \\
\text { Intercept }\end{array}$} & \multicolumn{6}{|c|}{$\begin{array}{l}\text { judge the trustworthiness of health- } \\
\text { related information in the media }\end{array}$} & \multicolumn{6}{|c|}{$\begin{array}{l}\text { understand and assess relevant } \\
\text { political topics }\end{array}$} \\
\hline & \multicolumn{4}{|c|}{ Model E1 } & \multicolumn{2}{|c|}{ Model E2 } & \multicolumn{3}{|c|}{ Model F1 } & \multicolumn{3}{|c|}{ Model F2 } \\
\hline & 1.21 & $* * *$ & $(1.04)$ & 2.25 & *** & $(1.25)$ & 8.31 & $* * *$ & $(1.07)$ & 266.2 & $* * *$ & $(1.42)$ \\
\hline \multicolumn{13}{|c|}{ Literacy Level (ref.: Above level 4) } \\
\hline Alpha level 1 & 0.08 & & $(3.49)$ & 0.14 & & (3.39) & 0.04 & $* * *$ & $(2.06)$ & 0.15 & $*$ & $(2.24)$ \\
\hline Alpha level 2 & 0.40 & $* *$ & $(1.31)$ & 0.58 & & $(1.35)$ & 0.16 & $* * *$ & $(1.26)$ & 0.68 & & $(1.37)$ \\
\hline Alpha level 3 & 0.53 & $* * *$ & $(1.17)$ & 0.71 & * & $(1.18)$ & 0.24 & $* * *$ & $(1.19)$ & 0.67 & & $(1.26)$ \\
\hline Alpha level 4 & 0.80 & $*$ & $(1.11)$ & 0.99 & & $(1.11)$ & 0.48 & $* * *$ & $(1.18)$ & 0.81 & & $(1.20)$ \\
\hline \multicolumn{13}{|c|}{ Educational attainment (ref.: high attainment) } \\
\hline No educational attainment & & & & 0.47 & $* * *$ & $(1.22)$ & & & & 0.44 & $* *$ & (1.29) \\
\hline
\end{tabular}




\begin{tabular}{|c|c|c|c|c|c|c|c|c|}
\hline \multirow[b]{2}{*}{ Low educational attainment } & \multicolumn{4}{|c|}{$\begin{array}{l}\text { judge the trustworthiness of health- } \\
\text { related information in the media }\end{array}$} & \multicolumn{4}{|c|}{$\begin{array}{l}\text { understand and assess relevant } \\
\text { political topics }\end{array}$} \\
\hline & & 0.53 & $* * *$ & $(1.10)$ & & 0.49 & $* * *$ & $(1.19)$ \\
\hline Medium educational attainment & & 0.69 & $* * *$ & $(1.09)$ & & 0.69 & $*$ & $(1.16)$ \\
\hline Still going to school & & 1.75 & $*$ & $(1.32)$ & & 0.62 & & $(1.34)$ \\
\hline \multicolumn{9}{|l|}{ Employment status (ref.: full-time employed) } \\
\hline Part-time employed & & 1.17 & & $(1.09)$ & & 0.84 & & $(1.15)$ \\
\hline Unemployed & & 0.88 & & $(1.16)$ & & 0.71 & & $(1.22)$ \\
\hline $\begin{array}{l}\text { In school, university, vocational training, } \\
\text { voluntary year }\end{array}$ & & 0.99 & & $(1.18)$ & & 0.67 & & $(1.29)$ \\
\hline Pensioner & & 1.22 & & $(1.13)$ & & 0.87 & & $(1.24)$ \\
\hline Unable to work & & 0.65 & * & $(1.22)$ & & 0.48 & $*$ & $(1.35)$ \\
\hline Other & & 1.12 & & $(1.13)$ & & 0.65 & $*$ & $(1.19)$ \\
\hline \multicolumn{9}{|l|}{ Age group (ref.: 18-24 years) } \\
\hline $25-34$ years & & 1.01 & & $(1.16)$ & & 1.19 & & $(1.25)$ \\
\hline $35-44$ years & & 1.20 & & $(1.17)$ & & 1.41 & & $(1.26)$ \\
\hline $45-54$ years & & 0.88 & & $(1.16)$ & & 1.46 & & $(1.25)$ \\
\hline $55-64$ years & & 1.02 & & $(1.17)$ & & 1.69 & $*$ & $(1.27)$ \\
\hline Low general interest in health/political topics & & 0.82 & $* * *$ & $(1.04)$ & & 0.41 & $* * *$ & $(1.05)$ \\
\hline Non-native German speaker & & 0.99 & & $(1.14)$ & & 0.53 & $* * *$ & $(1.19)$ \\
\hline $\mathrm{R}^{2}$ & 0.013 & 0.038 & & & 0.066 & 0.260 & & \\
\hline
\end{tabular}

Note. Exponents of standard errors are in parentheses. Ref. = reference category. Cont. = continuous variable. Source: LEO $2018-$ living with low literacy. Base: German speaking adults $(n=7.192){ }^{* * *} p<.001 .{ }^{* *} p<.01 .{ }^{*} p<.05$.

\section{Discussion}

In summary, we were able to show some exclusion and marginalization in relation to having low literacy skills, mainly regarding autonomy and critical understanding of information. At the same time, we saw that not all practices, which may include reading or writing, automatically exclude adults who have low literacy skills in the same way.

We were interested in the use of internet and specifically different forms of reading and writing digitally. Our findings suggest an ambivalent answer to these questions.

\section{Adults Who Have Low Literacy Skills Are Not Necessarily Excluded from Writing Online}

The tendency to write comments on news articles online seems to depend more on the individuals' age and it showed no correlation with having low literacy skills. This confirms findings that lower literacy levels do not necessarily stop adults from interacting in current debates (Dutz \& Heilmann, 2019). We cannot make any statements about the form or length in which these comments are written. They may be continuing text or also symbols, single words, short sentences. Partly, the written comments could also be explained by online comments often being conceptionally oral and are subject to different rules and norms (Storrer, 2014). Commenting online does not seem to include significant literacy-related barriers.

This, however, seems not to be true for searching for health-related information online. This practice reveals a larger and significant literacyrelated exclusion. This question shows that adults 
who have low literacy skills are less likely to search online for health-related information. Keeping in mind that this probably might be a population with higher health risks (cf. Conti et al., 2010), this lower extent of search-behavior might point into the direction of an exclusion.

This, in parts, confirms the research of Zillien and Marr (2013), which showed that the main social inequality does not necessarily appear with the general access to internet, but instead in the usage of online information and opportunities (cf. Reder, 2014; Smythe, \& Breshears, 2017). We were able to determine a low level of literacy skills to be one of the resources that affect the benefit one can gain from the internet access. At the same time, digitalization can offer new areas of communication. Rules for reading and writing online differ and therefore allow for more people who have low literacy skills to be included.

\section{Adults Who Have Low Literacy Skills Often Depend on Support to Fill in Forms}

Regarding the second set of questions we raised, we were able to show that a low level of literacy skills substantially increases the probability of a person always using support to fill in forms.

If a person always makes use of such an assistance, this might indicate a need to do so and thus a dependency on this assistance. A person who has low literacy skills might not be immediately excluded, hurt by, or at risk through this dependency, but it limits their autonomy and increases their likelihood of being hurt. Following Hurst's (2008, p. 191) definition of vulnerability as being at a greater risk to be wronged, we can identify the required forms at health services and social services as moments of increased vulnerability for adults who have low literacy skills. We were able to show that adults who have low literacy skills are often forced to rely on the support of others and are therefore restricted and limited in their autonomy.

\section{Low Literacy Relates to Lower Competences to Critically Understand and Judge Information and Issues}

Our third set of research questions focused on the extent to which adults who have low literacy skills trust themselves to understand different types of information. The two regression analyses demonstrated that people who have low literacy skills are less likely to do so. For them, it is more difficult to understand and assess a political topic and to judge health-related information critically. We have taken up the philosophical considerations on the relevance of critical literacy and critical competences (cf. Negt, 1969, 1993; Zeuner, 2007) and examined what role functional literacy (in the sense of functional competence to read and write) plays for these competences. We were able to show that people who have low literacy skills are clearly disadvantaged. The disadvantage is not explainable by general educational attainments but seems to be more closely connected to literacy skill itself.

\section{Limitations}

The literacy levels in the LEO survey can make no statement on individual cases or relations. All practices and competences are self-reported. They may include a response-bias (c.f. Edele et al., 2015). At the same time, certain (political or social) practices may include some socially desirable response sets and thus enhance these responses.

\section{Conclusion and Implications}

We set out to identify vulnerability in relation to low literacy skills. Maybe surprisingly, the vulnerability we found is not directly apparent in all writing practices, but more so in those 
practices and competences which are indirectly related to literacy. We found an increased exclusion of adults who have low literacy skills regarding access to digital health-related information and regarding the understanding of that information. We found that adults who have low literacy skills have more difficulties with judging whether a health-related information is trustworthy. In cases where they are required to fill in forms for health services or social services, they are more likely to require assistance of others to do so. This dependency additionally increases their vulnerability as well.

Adults who have low literacy skills have more difficulties understanding political issues, but not necessarily participate in online political discussions less frequently. This shows that a low level of literacy skills does not immediately exclude adults from political participation. It also shows the possibilities that online participation might bring. In many online forums, different rules for reading and writing apply and therefore empower especially those adults who struggle using the legitimate literacy. These adult's writing online might also indicate that they read and write in other instances, which have not yet been acknowledged as legitimate literacy practices by adult educators or adult education research. In addition, there is a difference in how independent people are, for example, when it comes to filling out forms.
The non-significant differences for literacy in writing online show that adults do exercise literacy practices that are currently seldom acknowledged as forms of literacy competences in adult education or research. These might be socially relevant for the respective adults and should therefore be more acknowledged. That fact that adults who have low literacy skills make frequent use of social media also gives a hint that social media might be used more systematically to reach future participants in adult basic education.

Both exemplary questions on the autonomy of adults who have low literacy skills showed that especially adults with literacy in alpha level 1 are far more dependent on others when accessing the health care system or social services. While educators should keep these difficult situations in mind, adults who struggle with their literacy might benefit from easier accessible social institutions. Institutions might serve as gatekeepers to adult learning, but it has been shown that authorities and institutions of social counselling rarely put adults with low literacy skills in touch with providers of adult education is often in need of improving (Angermeier \& Ansen, 2020; Buddeberg, 2019).

In summary, it may not be enough for adult education to focus on literacy itself. Rather, people also need a deeper contextual understanding and an equal access to trustworthy information as part of adult education. 


\section{References}

Allen, J., Velden, R. van der, Helmschrott, S., Martin, S., Massing, N., Rammstedt, B., Zabal, A., \& Davier, M. von. (2016). The development of the PIAAC Background Questionnaire. In I. Kirsch (Ed.), Technical report of the Survey of Adult Skills (PIAAC) (pp. 3,1-48). Organisation for Economic Co-operation and Development (OECD). https://madoc.bib.unimannheim.de/54544/

Andreassen, H. K., Bujnowska-Fedak, M. M., Chronaki, C. E., Dumitru, R. C., Pudule, I., Santana, S., Voss, H., \& Wynn, R. (2007). European citizens' use of E-health services: A study of seven countries. BMC Public Health, 7, 53. https://doi.org/10.1186/1471-2458-7-53

Andreasson, K. (2015). Tackling future digital divides. In K. Andreasson (Ed.), Public administration and public policy. Digital divides: The new challenges and opportunities of e-inclusion (pp. 265-276). Taylor and Francis.

Angermeier, K., \& Ansen, H. (2020). Value and understanding of numeracy practices in German debt counselling from the perspective of professionals. $Z D M$, 52(2).

Barton, D., \& Hamilton, M. (2003). Literacy practices. In D. Barton, M. Hamilton, \& R. Ivanič (Eds.), Literacies. Situated literacies: Reading and writing in context (pp. 6-14). Routledge.

Barton, D., Hamilton, M., \& Ivanič, R. (Eds.). (2003). Literacies. Situated literacies: Reading and writing in context (Reprinted.). Routledge.

Bremer, H., \& Pape, N. (2017). Literalität und partizipation als milieuspezifische soziale praxis. In B. Menke \& W. Riekmann (Eds.), Politische Grundbildung. Inhalte - Zielgruppen - Herausforderungen (pp. 56-73). Schwalbach/Ts.: Wochenschau Verlag.

Borgonovi, F., \& Pokropek, A. (2016). Education and SelfReported Health: Evidence from 23 countries on the role of years of schooling, cognitive skills and social capital. PloS One, 11(2), e0149716. https://doi.org/10.1371/ journal.pone.0149716
Buddeberg, K. (2019). Supporters of low literate adults. International Journal of Lifelong Education, 33(3), 1-13. https://doi.org/10.1080/02601370.2019.1600059

Buddeberg, K., Dutz, G., Grotlüschen, A., Hartig, J., Heilmann, L., \& Stammer, C. (2020). Verhältnis der Kompetenzstufen in PIAAC und LEO 2018. In A. Grotlüschen \& K. Buddeberg (Eds.), LEO 2018 Leben mit geringer Literalität (353-367). wbv.

Conti, G., Heckman, J., \& Urzua, S. (2010). The educationhealth gradient. American Economic Review, 100(2), 234-38. https://doi.org/10.1257/aer.100.2.234

Cutler, D. M., \& Lleras-Muney, A. (2010). Understanding differences in health behaviors by education. Journal of Health Economics, 29(1), 1-28. https://doi. org/10.1016/j.jhealeco.2009.10.003

Doyal, L., \& Gough, I. (1991). A theory of human need. Macmillan.

Dutz, G., \& Heilmann, L. M. (2019). Lesekompetenz und politische partizipation: Empirische Befunde aus PIAAC-L.

Edele, A.; Seuring, J.; Kristen, C.; Stanat, P. (2015): Why bother with testing? The validity of immigrants' selfassessed language proficiency. Social Science Research 52, 99-123.

Egloff, B., Grosche, M., Hubertus, P., \& Rüsseler, J. (2011). Funktionaler Analphabetismus im Erwachsenenalter: eine Definition. In Projektträger im Deutschen Zentrum für Luft- und Raumfahrt (Ed.), Alphabetisierung und Grundbildung Erwachsener: Vol. 1 Zielgruppen in Alphabetisierung und Grundbildung Erwachsener: Bestimmung, Verortung, Ansprache (pp. 11-32). Bertelsmann.

Freire, P. (2014). Pedagogy of the oppressed: $30^{t h}$ anniversary edition. Bloomsbury Publishing.

Geyer, S. (2008). Social inequalities in the incidence and case fatality of cancers of the lung, the stomach, the bowels, and the breast. Cancer Causes \& Control, 19(9), 965-974. https://doi.org/10.1007/s10552-008-9162-5 
Grotlüschen, A; Buddeberg, K. (Eds.) (2020). LEO 2018: Leben mit geringer Literalität. wbv Media

Grotlüschen, A., Buddeberg, K., Dutz, G., Heilmann, L., \& Stammer, C. (2019). Practices and competencies evidence from an adult literacy survey in Germany. In M. Schemmann (Ed.), Internationales Jahrbuch der Erwachsenenbildung / International yearbook of adult education (pp. 17-34). wbv.

Grotlüschen, A., Buddeberg, K., Dutz, G., Heilmann, L., \& Stammer, C. (2020a). Low literacy in Germany. Results from the second German literacy survey. European Journal for Research on the Education and Learning of Adults, 11(1).

Grotlüschen, A., Buddeberg, K., Dutz, G., Heilmann, L., \& Stammer, C. (2020b). Hauptergebnisse und Einordnung zur LEO-Studie 2018 - Leben mit geringer Literalität. In A. Grotlüschen \& K. Buddeberg (Eds.), LEO 2018: Leben mit geringer Literalität (pp. 9-52). wbv Media

Grotlüschen, A., Chachashvili-Bolotin, S., Heilmann, L., \& Dutz, G. (2020). Beyond literacy and language provision: Socio-political participation of migrants and large language minorities in five countries from PIAAC R1/R2. Journal of Adult and Continuing Education, 49(3). https://doi.org/10.1177/1477971419898491

Grotlüschen, A., Mallows, D., Reder, S., \& Sabatini, J. (2016). Adults with low proficiency in literacy or numeracy. OECD Education Working Papers: Vol. 131: OECD Publishing.

Grotlüschen, A., Riekmann, W., \& Buddeberg, K. (2014). Functional illiteracy in Germany. In H. Hinzen \& J. H. Knoll (Eds.), Lifelong learning and governance. From programming to action - selected experiences from Asia and Europe (pp. 55-67). Ventiane, SD.

Grotlüschen, A. (2016). Grundbildung. In R. Tippelt \& B. Schmidt-Hertha (Eds.), Handbuch Bildungsforschung (Vol. 5, pp. 1-18). [S.1.]: Springer Fachmedien Wiesbaden. https://doi.org/10.1007/978-3-531-20002-6_56-1

Harris, K., Jacobs, G., \& Reeder, J. (2019). Health systems and adult basic education: A critical partnership in supporting digital health literacy. Health Literacy Research and Practice, 3(3), S33-S36. https://doi. org/10.3928/24748307-20190325-02
Hurst, S. A. (2008). Vulnerability in research and health care; describing the elephant in the room? Bioethics, 22(4), 191-202. https://doi.org/10.1111/j.14678519.2008.00631.x

Lampert, T., \& Kroll, L. E. (2010). Armut und Gesundheit (GBE kompakt No. 5). Berlin.

Negt, O. (1969). Soziologische Phantasie und exemplarisches Lernen: Zur Theorie der Arbeiterbildung. Frankfurt am Main: Europäische Verlagsanstalt.

Negt, O. (1993). Wir brauchen eine zweite, gesamtdeutsche Bildungsreform. Gewerkschaftliche Monatshefte, 44, $657-668$.

Organisation for Economic Co-operation and Development. (2012). Literacy, numeracy and problem solving in technology-rich environments: Framework for the OECD Survey of Adult Skills. OECD Publishing.

Organisation for Economic Co-operation and Development. (2016). Skills matter: Further results from the survey of adult skills. OECD skills studies. OECD Publishing.

Organisation for Economic Co-operation and Development. (2018). The future of education and skills: Education 2030. OECD Publishing.

Reder, S. (2014). Digital inclusion and digital literacy in the United States: A portrait from PIAAC. http:// piaacgateway.com/us-piaac-conference

Reder, S. (2017). Adults' engagement in reading, writing and numeracy practices. http://pdxscholar.library.pdx. edu/ling_fac/22

Reder, S., \& Davila, E. (2005). Context and literacy practice. Annual Review of Applied Linguistics, 25, 170-187. https://doi.org/10.1017/S0267190505000097

Richter, M., \& Hurrelmann, K. (2009). Gesundheitliche Ungleichheit: Ausgangsfragen und Herausforderungen. In M. Richter \& K. Hurrelmann (Eds.), Gesundheitliche Ungleichheit: Grundlagen, Probleme, Perspektiven (pp. 13-33). VS Verlag für Sozialwissenschaften GWV Fachverlage GmbH, Wiesbaden. 
Smythe, S., \& Breshears, S. (2017). Complicating access: Digital inequality and adult learning in a public-access computing space. The Canadian Journal for the Study of Adult Education, 29(1), 67-81.

Sørensen, K., Pelikan, J. M., Röthlin, F., Ganahl, K., Slonska, Z., Doyle, G., \& Brand, H. (2015). Health literacy in Europe: Comparative results of the European health literacy survey (HLS-EU). European Journal of Public Health, 25(6), 1053-1058. https://doi. org/10.1093/eurpub/ckv043

Storrer, A. (2014). Sprachverfall durch internetbasierte Kommunikation? Linguistische Erklärungsansätze empirische Befunde. In Plewnia, A. Sprachverfall? Dynamik - Wandel - Variation (S. 171-196). De Gruyter.

Street, B. (1993). Introduction: The new literacy studies. In B. Street (Ed.), Cambridge studies in oral and literate culture: Vol. 23. Cross-cultural approaches to literacy (pp. 1-21). Cambridge University Press.

Street, B. (2003). What's "new" in the New Literacy Studies?: Critical approaches to literacy in theory and practice. Current Issues in Comparative Education, 5, 77-91.

Tillmann, K.-J., Dedering, K., Kneuper, D., Kuhlmann, C., \& Nessel, I. (2008). PISA als bildungspolitisches Ereignis: Fallstudien in vier Bundesländern (1. Aufl.). Schule und Gesellschaft: Vol. 43. VS Verlag für Sozialwissenschaften / GWV Fachverlage GmbH Wiesbaden.
UNESCO. (2005). Literacy for life: Education for All Global Monitoring Report 2006. EFA Global Monitoring Report: Vol. 4.

Vahtera, J., Virtanen, P., Kivimaki, M., \& Pentti, J. (1999). Workplace as an origin of health inequalities. Journal of Epidemiology \& Community Health, 53(7), 399-407. https://doi.org/10.1136/jech.53.7.399

Van Deth, J. W. (2016). Political Participation. In G. Mazzoleni (Ed.), The international encyclopedia of political communication. Wiley Blackwell.

Waldow, F. (2009). What PISA did and did not do: Germany after the 'PISA-shock'. European Educational Research Journal, 8(3), 476-483. https://doi.org/10.2304/ eerj.2009.8.3.476

Zeuner, C. (2007). Gerechtigkeit und Gerechtigkeitskompetenz: Diskurs und Praxis für eine kritische politische Bildung. Report - Zeitschrift für Weiterbildungsforschung, 30, 39-48.

Zeuner, C., \& Pabst, A. (2011). Lesen und Schreiben eröffnen eine neue Welt!" Literalität als soziale Praxis: Eine ethnographische Studie. s.1.: Bertelsmann W. Verlag.

Zillien, N., \& Marr, M. (2013). The digital divide in Europe. In M. Ragnedda \& G. W. Muschert (Eds.), Routledge advances in sociology: Vol. 73. The digital divide: The internet and social inequality in international perspective (pp. 55-66). Routledge. 